\title{
W POSZUKIWANIU WSPÓŁCZESNEGO KSZTALTU SAMORZĄDU TERYTORIALNEGO
}

Niezwykle trudno jest pisać o początkach odbudowy samorządu terytorialnego w ramach naszej transformacji komuś, kto - tak jak niżej podpisany - tkwił w tym procesie po uszy. Trudno zdobyć się przede wszystkim na obiektywizm, takim ujęciem z daleko lepszym skutkiem powinny się zając osoby zdystansowane wobec tamtych zdarzeń. Wydaje mi się natomiast, że znacznie ciekawsze, a nawet i bardziej wartościowe, może się okazać z tego punktu widzenia przytoczenie takich faktów, które mogą umknąć najwnikliwszemu nawet szkiełku i oku prawdziwego badacza, a które mogą być cennym uzupełnieniem obrazu wyłaniającego się z dokumentów i aktów prawnych - obrazu postrzeganego z pozycji bezpośredniego współuczestnika zdarzeń. Dlatego też, odpowiadając na zaproszenie do wypowiedzi na tych łamach, nie bronię się od subiektywnego spojrzenia na tamten niezwykły czas. Będzie też sporo o osobach, które wniosły najwięcej w to wspólne dzieło, bo przecież wszystko zawsze zależy od konkretnych ludzi - nawet wtedy, kiedy analizujemy zdarzenia, procesy, uwarunkowania, a tym bardziej koncepcje; one zawsze rodzą się bowiem w indywidualnych głowach.

Z perspektywy dwudziestopięciolecia odrodzenia samorządu terytorialnego w Polsce może się też dziś wydawać, że proces jego przywracania był zajęciem łatwym i przyjemnym. W pewnym sensie nauczyliśmy się wszyscy przez te lata oddychać samorządem jak powietrzem i być może dopiero wtedy, gdyby go nam zabrakło, szybko pojawiłyby się oznaki nieznośnej duszności. Ale na razie nikt otwarcie nie kwestionuje istnienia samorządu, więc pewnie obawy, że może się coś w tej materii niekorzystnie zmienić, sa nieuzasadnione. Ale nie ma też, oczywiście, absolutnej pewności, że wbudowanie samorządu terytorialnego $\mathrm{w}$ nasz system prawnoustrojowy jest już zjawiskiem trwałym i nieodwracalnym. Tak wydaje się teraz, ale jak będzie w przyszłości? Jakie jeszcze wiatry zawieją? I z której strony?

Może się także okazać - i to jest niebezpieczeństwo znacznie bardziej realne - że drobne, ale liczne zmiany pierwotnego założenia moga prowadzić w dłuższym okresie do zupełnie innej jakości instytucjonalnej, wręcz sprzecznej z istotą koncepcji początkowej. Co więcej - wydaje się, że owe drobne na pozór zmiany doprowadziły po 25 latach do takiego stanu polskiego samorządu, w którym wręcz trudno rozpoznać jego pierwotnie zakładany kształt. Nieodżałowany Michał Kulesza wielokrotnie w ostatnich latach swojego życia z goryczą konstatował, że oto wróciliśmy niemal do punktu wyjścia, czyli do kon- 
trolowanych centralnie rad narodowych z bezradnymi radnymi, a najbardziej dobitnie dał temu wyraz w głośnej publikacji $O$ tym, ile jest decentralizacji $w$ centralizacji, a także o osobliwych nawykach uczonych administratywistów ${ }^{1}$.

Niżej podpisany w wywiadzie dla jednej z poczytnych gazet uznał na tydzień przed ostatnimi wyborami samorządowymi, że trudno obecnie mówić już o samorządzie - właściwszym słowem byłoby tu samodzierżawie ${ }^{2}$.

Jeśli jubileusze maja jakiś sens, to tylko o tyle, o ile z ich okazji jesteśmy zdolni do poddania przebytej drogi pogłębionej refleksji. Z tego punktu widzenia obchodzone - trzeba powiedzieć, że szumnie - ćwierćwiecze odrodzonego samorządu terytorialnego w Polsce wyjątkowo dobrze się do tego celu nadaje. Minęło bowiem wystarczająco dużo czasu, by można było wyłuskać z powodzi zdarzeń te, które w sposób najbardziej znaczący wpłynęły na przemiany ustroju lokalnego i które najsilniej determinują jego obecny kształt.

\section{PIERWSZA KONFRONTACJA}

Zmagania strony solidarnościowej przy Okragłym Stole z przedstawicielami strony koalicyjno-rządowej, jak określano wtedy reprezentantów ustępujacego pola establishmentu, są stosunkowo dobrze opisane - szczególnie w publikacjach prof. prof. Jerzego Regulskiego i Michała Kuleszy ${ }^{3}$. Strona solidarnościowa otwarcie i zdecydowanie domagała się wówczas zagwarantowania, że przywracanie samorządu musi opierać się na klasycznym instrumentarium zachodniej władzy lokalnej, z czym wiązała się osobowość prawna gminy i wynikające z niej konsekwencje w postaci odrębnej od mienia Skarbu Państwa instytucji mienia komunalnego oraz prawnofinansowej odrębność budżetów gmin od budżetu państwa, a także niezwykle istotna kwestia granic nadzoru nad samorządem - nadzoru ograniczonego do badania legalności i zasadniczo bez analizy celowości działania. Generalnie chodziło tu o gwarancje realnej samodzielności samorządu terytorialnego.

Druga strona (tzw. koalicyjno-rządowa) z kolei równie twardo stała na stanowisku zachowania dotychczasowego status quo, wynikającego na dobra sprawę z uregulowań uchwalonej przez Sejm stosunkowo niedawno (w 1983 r.) ustawy o radach narodowych i samorządzie terytorialnym ${ }^{4}$, w której rolę samorządu ograniczono $\mathrm{w}$ istocie do przestrzeni sołectw $\mathrm{i}$ osiedli.

Pewnym krokiem we właściwym kierunku było wprowadzenie do tej ustawy samego pojęcia „samorząd terytorialny”, które do tego czasu było owocem

1 „Samorząd Terytorialny” 19, 2009, nr 12, s. 15.

2 Samorzqd nam się wykoślawit, „Gazeta Wyborcza” z 11 listopada 2014 r.

${ }^{3}$ Reforma samorzqdowa. Materiaty źródtowe 1980-1990, wstęp i wybór J. Regulski, Fundacja Rozwoju Demokracji Lokalnej, Warszawa 2000; J. Regulski, Reformowanie państwa - moje doświadczenie, Szczecin 2007; M. Kulesza, J. Regulski, Samorzqd III Rzeczypospolitej. Koncepcje i realizacja, Warszawa 2000; J. Regulski, M. Kulesza, Droga do samorzadu. Od pierwszych koncepcji do inicjatywy Senatu (1981-1989), Warszawa 2009.

${ }^{4}$ Ustawa z 20 lipca 1983 r., Dz. U. Nr 41, poz. 185, znowelizowana ustawą z 16 czerwca 1988 r., Dz. U. Nr 19, poz. 130. 
całkowicie zakazanym, bo rósł tylko w krajach burżuazyjnych, niemniej jednak jego rola była sprowadzona do statusu bliżej nieokreślonej organizacji społecznej. W każdym razie władzę publiczną (państwowa) rezerwowano wyłacznie dla rad narodowych, które miały funkcjonować nadal w ramach jednolitego systemu organów państwa.

Okragły Stół był oczywiście ważnym krokiem w przybliżaniu idei samorządu terytorialnego, bo o prawdziwym samorządzie już się wtedy oficjalnie mówiło, ale w związku ze stanowczymi - jak się okazało - i nie do pogodzenia stanowiskami stron ostatecznie przyjęto zgodnie deklarację, że samorząd będzie funkcjonował wyłącznie w gminie. O uzgodnieniu szczegółów nie było już mowy. Strony zakończyły obrady podstolika samorządowego długim protokołem rozbieżności.

Niebawem jednak historia gwałtownie przyśpieszyła, a wynik głosowania 4 czerwca nie pozostawiał watpliwości co do tego, czego oczekuje społeczeństwo. Na marginesie podkreślmy, że aczkolwiek wynik wyborów czerwcowych był mocno zafałszowany obowiąującą wówczas sejmową ordynacją wyborcza, która przewidywała, że dwie trzecie mandatów z góry przypadnie kandydatom partii rządzącej i jej satelitom, to wszyscy uważnie studiowali wówczas, i słusznie, nie wyniki wyborów, ale wyniki głosowania, a z nich wynikało, że przy 60-procentowej frekwencji około 65\% wyborców głosowało na kandydatów Solidarności. Te liczby wyjaśniały wszystko. Alternatywą dla zaakceptowania wyniku głosowania mogło być tylko unieważnienie wyborów czerwcowych. Technicznie władza mogła to oczywiście uczynić, ale ryzyko awantury na międzynarodową skalę było zbyt wielkie. A czy można sobie w ogóle w tamtym czasie wyobrazić, że społeczeństwo taką powtórkę ze stanu wojennego mogłoby zaakceptować?

Na dodatek w Sejmie X kadencji znalazło się w klubach obozu rządzącego ponad 100 osób, które formalnie reprezentowały wprawdzie ten obóz, ale trafiły do parlamentu dzięki mniej lub bardziej wyraźnemu poparciu Solidarności. W pierwszej chwili pełny obraz wybranego parlamentu jeszcze nie ujawnił swoich prawdziwych barw, ale już pierwsze głosowania w Sejmie kontraktowym pokazały, gdzie jest prawdziwa siła. Wynikała ona z innego niż klubowy podziału mandatów, ponieważ ta „setka” prosolidarnościowych posłów, zsumowana ze 165 posłami Obywatelskiego Klubu Paralmentarnego (OKP), dawała w pewnych głosowaniach zdecydowaną większość, pozwalającą na przyjmowanie najważniejszych ustaw, takich jak np. plan Balcerowicza. Odnosi się to także do głosowania ustaw samorządowych, choć nie w pełni. Jeśli więc przy okazji recenzowania prac Okragłego Stołu mówi się od czasu do czasu o tajnym porozumieniu z Magdalenki, które rzekomo miało rzutować na następne lata, a przede wszystkim na działania rządu Tadeusza Mazowieckiego, to wynik głosowania i wyborów z 4 czerwca 1989 r. nie pozostawiał żadnej wątpliwości: obóz rządzący musiał oddać władzę, ponieważ nawet we własnych szeregach nie mógł liczyć na lojalność.

Ostatecznie doszło nie do oddania władzy, ale do podzielenia się nia, i to - jak już dziś wiemy - głównie z powodu stanowiska Stanów Zjednoczonych, których administracja bała się niekontrolowanego zamieszania w związku z wyborami prezydenta. Pamiętajmy, że Armia Czerwona wyszła z Polski do- 
piero 17 września 1993 r., czyli cztery lata później. Nikt nie chciał wtedy ryzykować i sprawdzać, gdzie są granice ustępstw ze strony naszego wschodniego sąsiada. A jeśli nawet głośno tego się domagał, traktowano go zwykle jako co najmniej agenta wpływu.

\section{W SENACIE I KADENCJI}

Podniesienie więc przez Obywatelski Klub Parlamentarny kwestii przywrócenia samorządu terytorialnego na samym początku ukonstytuowania się nowego parlamentu, a przede wszystkim Senatu, wydawało się w tym kontekście przedsięwzięciem stosunkowo bezpiecznym. Na pierwszych posiedzeniach Senatu, wybranego - co należy podkreślić - w całkowicie wolnych wyborach, pojawiło się kilka co prawda innych propozycji inicjatyw legislacyjnych, m.in. w zakresie służby zdrowia, szkolnictwa wyższego czy pewnych rozwiązań dotyczących rolnictwa, ale szybko okazało się, że tylko grupa skupiona wokół prof. Jerzego Regulskiego ma jasną i spójną koncepcję swojego głównego planu. Nie poszedł więc na marne kilkuletni wysiłek związany z pracami studialnymi poświęconymi samorządowi, jakie prowadził prof. Regulski jeszcze w ramach konwersatorium „Doświadczenie i przyszłośc””, inspirowany do tego przez Stefana Bratkowskiego, Bogdana Gotowskiego i Andrzeja Wielowieyskiego, choć prace te były prowadzone bez pewności, że kiedykolwiek posłużą do zbudowania prawdziwego samorządu terytorialnego za życia podejmujacych te wysiłki.

$\mathrm{Z}$ czasem do prof. Regulskiego dołączali niezbyt liczni, ale za to bardzo znaczący badacze i protagoniści odrodzenia samorządu, jak, wówczas jeszcze doktor, Michał Kulesza czy dr hab. Walerian Pańko. Wśród uczniów prof. Regulskiego dał się samorządowo szczególnie dobrze poznać dr Iwo Byczewski. Niżej podpisany dołączył do tego grona dopiero w trakcie obrad Okragłego Sto$\nmid u-z$ racji kilkuletniego wcześniejszego zaangażowania się $\mathrm{w}$ problematykę samorządową na łamach pisma „Samorządna Rzeczpospolita”, wychodzącego poza zasięgiem cenzury, którego celem było trwałe przypominanie dorobku programowego I Zjazdu Solidarności w 1981 r. Program Związku zdecydowanie postulował m.in. przywrócenie samorządu terytorialnego, a także m.in. powołanie Rzecznika Praw Obywatelskich i Trybunału Konstytucyjnego.

O ile grupa prof. Regulskiego upatrywała w samorzadzie przede wszystkim remedium na niedostatki planowania przestrzennego (zarówno Jerzy Regulski, jak i Michał Kulesza czy Walerian Pańko zajmowali się wcześniej tą problematyką naukowo), o tyle w moim wypadku decydujące były podstawowe wątki cywilizacyjne, których nośnikiem jest właśnie samorząd terytorialny. Właśnie ten aspekt sprawdzonej historycznie instytucji obywatelskiej przyciagnął w drugiej połowie lat osiemdziesiątych uwagę krakowskiego filozofa Mirosława Dzielskiego, czemu dał wyraz w eseju z 1987 r. pod symptomatycznym tytułem Powrót cywilizacji ${ }^{5}$, wprowadzając nową jakość do ówczesnej dyskusji publicznej, co prawda wówczas jeszcze toczącej się tylko w podziemiu.

${ }^{5}$ M. Dzielski, Odrodzenie ducha - budowa wolności. Pisma zebrane, Kraków 1995, s. 215. 
Wieloletnie studia nad istotą samorządności, a także świeże doświadczenia zebrane w toku okragłostołowego dyskursu, a przede wszystkim w toku kampanii wyborczej poprzedzającej wybory 4 czerwca 1989 r. sprawiły, że grupa skupiona wokół Jerzego Regulskiego mogła niemal na drugi dzień po tych wyborach przystapić do formowania realnego programu przywracania polskiemu porządkowi ustrojowemu samorządu terytorialnego w takiej postaci, która z jednej strony nawiąywała do doświadczeń przedwojennych, a z drugiej uwzględniała także osiagnięcia aktualnej myśli europejskiej, najpełniej wyrażonej w Europejskiej karcie samorządu lokalnego, uchwalonej w 1985 r.

Już 29 lipca 1989 r. Senat przyjął uchwałę o rozpoczęciu prac legislacyjnych $\mathrm{z}$ zadaniem stworzenia głównych podstaw prawnych do przywrócenia samorządu, powierzając te prace powołanej już wcześniej Komisji Samorządu Terytorialnego z przewodniczącym Jerzym Regulskim. Niebawem życie publiczne zaczęło się toczyć jeszcze szybciej, a to z powodu powołania 12 września gabinetu Tadeusza Mazowieckiego. 18 września 1989 r. utworzona została przez czterech senatorów i jednego posła OKP ${ }^{6}$ Fundacja Rozwoju Demokracji Lokalnej, której głównym zadaniem już w nieodległej przyszłości będzie przygotowanie kadr dla mającego powstać samorządu. Tadeusz Mazowiecki zdecydował o powołaniu Jerzego Regulskiego na stanowisko pełnomocnika rządu ds. samorządu terytorialnego, jako podsekretarza stanu, i jednocześnie utworzył stanowisko sekretarza stanu odpowiedzialnego za terenową administrację rządową (wojewodów), powierzając tę funkcję prof. Jerzemu Kołodziejskiemu z Gdańska. Będzie to miało niebawem swoje negatywne reperkusje, o czym dalej. Odejście Jerzego Regulskiego na pozycję rządową spowodowało z kolei wybór niżej podpisanego na przewodniczącego senackiej Komisji Samorządu Terytorialnego, co wiązało się z obowiązkiem zbudowania zespołu ekspertów, którzy będą pracować nad propozycjami konkretnych rozwiązań ustawowych. Warto podkreślić, że na samym początku nastapił swego rodzaju podział pracy pomiędzy Senat i rząd, przy czym główne prace projektowe miały się toczyć w komisji senackiej, pełnomocnik rządu ds. samorządu zaś miał skoordynować prace nad podziałem zadań i kompetencji pomiędzy administrację rządowa i samorząd, Ministerstwo Finansów z kolei miało opracować założenia finansowania samorządu w nieco późniejszym czasie. Ta ostatnia ustawa została uchwalona przez Sejm dopiero jesienią 1990 r. - już po upływie kilku miesięcy od wyborów samorządowych. Nowy system finansów lokalnych mógł - z natury rzeczy - zaczaćc obowiązywać dopiero z początkiem następnego roku.

Wczesny etap prac w komisji senackiej nie zapowiadał szczególnych trudności. Do zespołu ekspertów został włączony dr Zygmunt Niewiadomski, który właśnie ukończył swoją pracę habilitacyjną na temat samorządu szwajcarskiego i francuskiego i oddał ją do druku po powrocie z dłuższego stypendium w tych krajach. Gromadząc różne materiały wyjściowe, włączyliśmy także do ich zbioru świeżo opublikowany w dwutygodniku „Rada Narodowa”7 projekt ustawy o samorządzie terytorialnym, współautorstwa dwóch profesorów

\footnotetext{
${ }^{6}$ Jerzy Regulski, Aleksander Paszyński, Andrzej Celiński, Jerzy Stępień i Walerian Pańko.

7 Z początkiem 1990 r. „Rada Narodowa” zmieni tytuł na „Wspólnota”, a pierwszym jej redaktorem zostanie Michał Kulesza.
} 
z Uniwersytetu Ślaskiego - Karola Podgórskiego i Karola Sobczaka. Profesor Karol Podgórski był przed wojną urzędnikiem województwa śląskiego i tym samym stał się jedynym naszym łącznikiem z praktyką administracyjną okresu międzywojennego. Grupa inicjująca przywrócenie samorządu była zdana wyłącznie na lekturę opracowań; nawet najstarszy w naszym gronie senackim Jerzy Regulski w chwili wybuchu wojny miał zaledwie piętnaście lat.

$\mathrm{Na}$ jednym z pierwszych posiedzeń senackiej Komisji Samorządu Terytorialnego pojawi się niebawem prof. Teresa Rabska z Uniwersytetu im. Adama Mickiewicza w Poznaniu, która będzie w senackiej grupie ekspertów długo jedynym przedstawicielem środowiska profesorów tytularnych. Po pewnym czasie będzie nas wspierał, jeśli idzie o ten szczebel establishmentu akademickiego, szczególnie w zakresie problematyki mienia komunalnego, jeszcze tylko prof. Tomasz Dybowski. Korzystać będziemy w końcowej fazie prac w Senacie w zakresie problematyki dochodów zwrotnych z wiedzy prof. Andrzeja Całusa z warszawskiej SGH. Główną podpora w części dotyczącej finansów od początku do końca była wówczas dr hab. Maria Gintowt-Jankowicz, która włączyła się w prace samorządowe jeszcze w czasie Okrągłego Stołu.

Wymieniam te nazwiska z kronikarskiego niejako obowiązku, ale także by zwrócić uwagę, że w tamtym czasie nie mogliśmy liczyć na szerokie wsparcie naszych prac ze strony środowisk uniwersyteckich. Większe grono eksperckie pojawi się kilka miesięcy później przy sejmowej Nadzwyczajnej Komisji ds. Samorządu Terytorialnego, ale będą to głównie naukowcy skupiający wcześniej swoją aktywność na problematyce rad narodowych i dość wyraźnie przywiązni do idei systemu jednolitej władzy państwowej, choć będą w tym gronie także sprzyjające nam wyjątki, tak jak w przypadku dr Czesławy Rudzkiej-Lorenz z SGH czy dr hab. Teresy Dębowskiej-Romanowskiej z Uniwersytetu Łódzkiego. Obie stały się niezwykle cenną podporą naszego kręgu eksperckiego na wiele następnych lat.

\section{PIERWSZE ROZCZAROWANIA}

Powołanie rządu Tadeusza Mazowieckiego dodało nam skrzydeł - byliśmy przekonani, że z tej strony możemy mieć tylko wsparcie, dość szybko okazało się jednak, że w sferach urzędniczych ówczesnego Urzędu Rady Ministrów gromadzą się osoby niesprzyjające reformie samorządowej. Już w październiku 1989 r. rozpoczęto tam - pod kierunkiem prof. Jerzego Kołodziejskiego - prace nad wprowadzeniem do systemu administracji rządowej rejonowych urzędów administracji ogólnej z jednoosobowymi kierownikami, a jednocześnie nawet z kręgów sejmowej części Obywatelskiego Klubu Parlamentarnego popłynęły sugestie, aby wprowadzenie samorządu odłożyć na dwa lata, a jeszcze w grudniu 1989 r. przeprowadzić wybory do nowych rad narodowych po skróceniu kadencji starych. Przyświecała temu idea skanalizowania energii lokalnych komitetów obywatelskich, które zdecydowanie parły do szybkiego przejęcia władzy politycznej szczególnie w miastach. Rozpoczęcie prac nad koncepcja 
rejonu administracji rządowej, uwieńczone ustawą o terenowych organach rządowej administracji ogólnej, przyjętej przez Sejm 22 marca 1990 r. ${ }^{8}$, zapowiadało, że pewne kręgi rządowe będą raczej skłonne rozbudowywać w przyszłości „w dół” hierarchię administracji centralnej, niż sprzyjać poszerzaniu sfery samorządności. Cała ta operacja odbyła się z uzasadnieniem, że gminy nie będą w stanie przejąć wszystkich zadań istniejącej od 1975 r. administracji rejonowej (dawniej powiatowej), a przeniesienie tych zadań na poziom województwa spowoduje usytuowanie organów II instancji w tych sprawach w ministerstwach, co będzie powodem oskarżenia nowych władz o centralizowanie w istocie zadań państwa.

Przekonywano w tym czasie niejako równolegle także i mnie, że w Senacie nie ma dostatecznie silnego intelektualnie zespołu, który mógłby legislacyjnie przygotować wprowadzenie tak fundamentalnej reformy. „Popracujecie z Michałem [Kulesza - przyp. J.S.] spokojnie przez dwa lata, a następnie prześlecie do Sejmu komplet potrzebnych, starannie opracowanych ustaw, włożonych do pudełka przewiązanego wstążeczka” - słyszałem od jednego z ważniejszych posłów OKP tamtego okresu. Rzeczywiście dysponowaliśmy niewielkim zespołem, ale za to niezwykle sprawnym i ambitnym. Ratunkiem w tej nieoczekiwanej sytuacji mógł być tylko marszałek Senatu prof. Andrzej Stelmachowski, który na szczęście zdążył już przywiązać się do myśli, że samorząd będzie statkiem flagowym odrodzonego Senatu.

„Proszę pracować dalej, a politykę zostawić mnie” - tak skomentował moja relację o realnych zagrożeniach dla całej reformy samorządowej. Członkowie komitetów obywatelskich, które powstały przez wyborami czerwcowymi i gwaltownie rozrosły się lokalnie zaraz po ich przeprowadzeniu, nie orientowali się w swoje masie w zawiłościach konstrukcji prawdziwego samorządu. Motywowała ich za to, i to bardzo silnie, myśl, że niebawem moga stać się prawdziwymi gospodarzami na swoim terenie. Komitety obywatelskie stanowiły nawet w pewnym momencie polityczne zagrożenie dla NSZZ „Solidarnośćc” i zostały przez Lecha Wałęsę rozwiązane. Na szczęście w zdecydowanej większości nie podporządkowały się tej decyzji - mogła więc powstać kuszacca politycznie myśl, by tę olbrzymią energię ludzi, autentycznie spragnionych daleko idących zmian i pełnych jak najlepszych intencji, skierować jak najszybciej do istniejących struktur lokalnej władzy, bez oglądania się na wyposażenie tejże władzy $\mathrm{w}$ odpowiednie instrumentarium instytucjonalne. Z pewnością wielu działaczy komitetów szybko zasmakowałoby władzy w zastanym kształcie, ale w efekcie mielibyśmy do czynienia ze zjawiskiem wlewania młodego wina do starych bukłaków z wiadomym skutkiem. Niewykluczone, że z ideą samorządu z prawdziwego zdarzenie musielibyśmy się - przy takim obrocie spraw - pożegnać na wiele lat, jeśli nie na zawsze. Mogłoby tak się stać całkiem realnie - wystarczy popatrzeć na doświadczenia innych krajów postkomunistycznych, które poszły droga usprawniania systemu rad narodowych.

Ostatecznie zdecydowano na najwyższym szczeblu, że wybory odbędą się w maju następnego roku oraz że będą to wybory w pełni samorządowe. Senat zyskiwał tym samym kilka miesięcy na przygotowanie koniecznych

${ }^{8}$ Dz. U. 1990, Nr 21, poz. 123. 
ustaw. Jednocześnie w Sejmie powołana została Nadzwyczajna Komisja ds. Samorządu Terytorialnego z prof. Walerianem Pańko jako przewodniczącym, która miała pracować równolegle z komisją senacką i niejako recenzować na bieżąco prace senackie. Ponieważ jednak teksty projektów ustaw powstawały w Senacie, obrady komisji sejmowej przypominały w tym okresie swoiste seminarium naukowe, w którym brali udział przede wszystkim eksperci zaproszeni wcześniej do Okragłego Stołu przez ówczesną stronę koalicyjno-rządowa. Z wypowiedzi posłów Sejmu kontraktowego, jak i wspierających ich ekspertów, wynikało wyraźnie, że „stronnictwo rad narodowych” nadal trzyma się mocno. Uważne śledzenie tych obrad pozwalało na szczęście zawczasu przygotować się na nieodległą w czasie konfrontację. Nie sposób bowiem było jej uniknąć.

\section{DRUGA KONFRONTACJA}

Projekt tzw. ustrojowej ustawy samorządowej uchwalony został przez Senat 19 stycznia 1990 r. Przewidywał on w szczególności:

- wyraźne rozdzielenie polityki i administracji w gminie przez utworzenie rady z jej przewodniczaccym i odrębnym organem wykonawczym w postaci zarządu z burmistrzem (wójtem, prezydentem dużego miasta) na czele, reprezentującym gminę na zewnątrz;

- utworzenie stanowiska dyrektora miasta (sekretarza gminy wiejskiej), stojącego na czele urzędu, co miało służyć pełnej realizacji zasady rozdzielenia funkcji politycznych od administracyjnych (bezpośrednio zarządczych). Zrealizowaniu w pełni tej koncepcji oddzielenia polityki od administracji miała także służyć tworzona w tym samym czasie niejako równolegle ustawa o pracownikach samorządowych, przewidujaca zatrudnianie najbardziej kompetentnych urzędników na podstawie mianowania;

- zamknięcie całego postępowania administracyjnego w sprawach indywidualnych $\mathrm{w}$ obrębie organów gminy przez powierzenie wydawania decyzji I instancji wójtowi (burmistrzowi, prezydentowi), z możliwością odwołania się do kolegium odwoławczego (II instancja), usytuowanego przy radzie gminy;

- utworzenie Krajowego Zwiazku Gmin, zrzeszajaccego z mocy prawa wszystkie gminy; Krajowy Związek Gmin miał wespół z Prezesem Rady Ministrów powoływać członków regionalnych izb obrachunkowych;

- możliwość tworzenia obowiąkowych związków dla konurbacji i metropolii z przyległościami - z myślą o utworzeniu takich związków w pierwszej kolejności dla miast Górnego Śląska, Trójmiasta i metropolii warszawskiej;

- wydania specjalnej ustawy o gminach uzdrowiskowych;

- radni mieli otrzymywać w związku ze swoją aktywnością nie diety, ale rzeczywistą rekompensatę z tytułu utraconych (zarobków) dochodów, a także pokrycie kosztów związanych ze sprawowaniem mandatu;

- w skład komisji rady mieli wchodzić członkowie spoza rady, zapraszani do nich ze względu na swoje zawodowe kwalifikacje. 
Z kolei senacki projekt ordynacji wyborczej przewidywał wybory większościowe z okręgami jednomandatowymi w zasadzie dla wszystkich rad o stosunkowo niewielkich składach osobowych.

Warto w tym miejscu odnotować, że pierwotny projekt senackiej Komisji Samorządu Terytorialnego zakładał łączenie w jednym ręku pozycji przewodniczącego rady z funkcją przewodniczącego zarządu, przy jednoczesnym powierzeniu kierownictwa urzędu dyrektorowi miasta (sekretarzowi gminy), co miało wzmocnić rozdział funkcji politycznych (z wyboru) od administracyjnych. Ta koncepcja nie znalazła jednak zrozumienia u większości senatorów. Argumentowano, że burmistrz jako jednocześnie przewodniczacy rady będzie skupiał w swoim ręku zbyt silną władzę i w konsekwencji przegłosowano rozdzielenie tych dwóch funkcji, wprowadzając jednocześnie przepis stwarzający możliwość wyboru burmistrza spoza członków rady, z utrzymaniem zasady, że burmistrz nawet spoza rady będzie reprezentował gminę w stosunkach zewnętrznych.

Nikt - jak sądzę - nie mógł wtedy przypuszczać, że po latach burmistrz, uniezależniony od rady przez bezpośrednie wybory, łącząc nadal jednocześnie w swoim ręku pozycję polityczną i administracyjną osiagnie status funkcjonariusza publicznego całkowicie marginalizującego radę. Na początku 1990 r. samo rozdzielenie pozycji przewodniczacego rady i burmistrza nie wydawało się jeszcze niebezpieczne dla zasady reprezentacji - zasady podstawowej dla zachodnioeuropejskiego modelu władzy lokalnej ${ }^{9}$, ponieważ organ wykonawczy organizacyjnie podlegał bezpośrednio radzie. Ale wprowadzone w 2002 r. bezpośrednie wybory wójta, będącego tym razem już jednoosobowym organem wykonawczym, doprowadziły do całkowitego odwrócenia wektora zależności. Od tej chwili funkcja kontrolna rady nad wójtem stała się już całkowicie iluzoryczna.

Przypomnijmy w tym kontekście, że w myśl EKSL (art. 3 ust. 1 i 2 ) samorząd terytorialny oznacza prawo i zdolność społeczności lokalnej, w granicach prawa, do kierowania i zarządzania zasadniczą częścią spraw publicznych na ich własną odpowiedzialność i w interesie ich mieszkańców, przy czym prawo to realizowane jest przez rady lub zgromadzenia, wybierane demokratycznie, które mogą dysponować organami wykonawczymi im podlegajacymi. Zauważmy, że w tekście angielskim Karty mowa o „councils or assemblies [...] which may possess executive organs responsible to them"10, co wyraźnie podkreśla nie tyle aspekt podległości, ile odpowiedzialność organu wykonawczego przed rada.

O tempie prac ustawodawczych tamtego okresu najlepiej świadczy fakt, że już 24 stycznia odbyło się pierwsze czytanie podstawowych ustaw samorządowych z dołączonym do nich projektem koniecznej nowelizacji Konstytucji. Ta faza procesu legislacyjnego nie zapowiadała w pierwszej chwili ataku posłów na podstawowe konstrukcje projektów senackich, ale w trakcie posiedzeń

${ }^{9}$ S. P. Huntington, Zderzenie cywilizacji i nowy kształt tadu światowego, Warszawa 1998, s. 35.

${ }^{10}$ Europejska karta samorządu terytorialnego, Dz. U. 1994, Nr 124, poz. 607 (dalej jako: „EKSL” lub „Karta”). 
nadzwyczajnej komisji sejmowej szybko się okazało, że posłowie będą raczej skłonni kwestionować wiele proponowanych rozwiązań, niż dokonywać niezbędnych korekt zgodnych z duchem projektu senackiego.

Jedna z najbardziej kontrowersyjnych kwestii stała się forma gratyfikacji pracy radnych. Projekt senacki przewidywał tu instytucje zwrotu utraconego przez radnego zarobku - w myśl regulacji art. 7 EKSL ${ }^{11}$. Chodziło tu o podkreślenie społecznego charakteru pracy radnych, ale z gwarancją wyrównania strat poniesionych w związku z ich aktywnością. W Sejmie zwyciężyła jednak koncepcja wypłacania radnym diet, niezależnie od tego, czy ich funkcja będzie rodzić jakieś koszty. Instytucja diety znana była poprzedniemu porządkowi w ramach systemu rad narodowych i na tyle silnie ugruntowana w mentalności posłów, że jej wyeliminowanie było dla nich wręcz niewyobrażalne. Warto byłoby po latach prześledzić tok rozumowania posłów w tamtym czasie na podstawie stenogramów sejmowych, bo byłaby to lekcja niezwykle pouczajacca dla uchwycenia atmosfery tamtego czasu - w każdym razie argument polegający na przytoczeniu regulacji EKSL zbywano uwaga, że przecież Polska nie jest członkiem Rady Europy i nie wiadomo, czy kiedykolwiek nim będzie.

Wydawać by się mogło, że owe nieszczęsne diety to problem marginalny. Szybko się jednak okazało, że przyjmowane przez rady regulaminy ustalania ich wysokości tak skutecznie mnożyły podstawy ich wypłacania, że już w drugiej kadencji samorządu w niektórych większych miastach zdarzali się tak „pracowici” radni, że potrafili osiagać z tego tytułu kilkutysięczne miesięczne dochody. Prasa warszawska zidentyfikowała w pewnym momencie radna, którą „zarobiła” w jednym miesiącu na dietach kwotę 8 tys. złotych, a tych najbardziej „pracowitych” ochrzczono „dietetykami”. Proceder windowania pułapu diet został częściowo ukrócony dopiero w następnej kadencji parlamentu (1997-2001) w drodze tzw. ustawy kominowej, która ograniczyła wysokość diet dla radnych w gminach do kwoty około $1500 \mathrm{zł}$, a w większych miastach do 2500 zł. Jeśli się zważy, że diety są nieopodatkowane, nietrudno zrozumieć, że dla wielu osób stały się one źródłem realnych dodatkowych, niemałych zarobków, budzących zazdrość współmieszkańców, a jednocześnie okazały się skutecznym instrumentem dyscyplinowania radnych ze strony dominujacych nad nimi od 2002 r. wójtów - lokalnych liderów układajaccych listy na użytek kolejnych wyborów.

Nie udało się także utrzymać projektowanego stanowiska dyrektora miasta. W koncepcji większości posłów wójt miał stać się kierownikiem urzędu gminy i tym samym łączyć w jednym ręku funkcje polityczne i administracyjne. Przekreślona została w ten sposób nadzieja na wprowadzenie w przyszłości do samorządu wysoko wykwalifikowanych urzędników, którzy zdolni byliby pełnić rolę city managerów - z pozycją w miarę niezależną od politycznych dysponentów. Z kolei bezpośrednie wybory wójta nie tylko wzmocniły i tak już dominującą jego rolę w stosunku do urzędników, szczególnie od momentu,

11 „Status ten [przedstawicieli wybieranych do władz lokalnych - przyp. J.S.] powinien zapewnić wyrównanie finansowe odpowiednio do kosztów poniesionych w związku z wykonywaniem mandatu oraz, w razie potrzeby, wyrównanie finansowe za utracone zyski lub też wynagrodzenie za wykonaną pracę, jak również odpowiednie ubezpieczenie społeczne”. 
w którym sekretarz gminy przestał być wybierany przez radę, co nastapiło z początkiem tego już wieku, ale na dodatek wprowadziły podział na dwa organy polityczne (z wyboru) - na radę i niezależnego od niej wójta. Tym samym zachodnioeuropejski model rozdziału stanowisk na polityczne i administracyjne uległ załamaniu, za to pojawiły się dwa organy polityczne, z których jeden (wójt) całkowicie podporządkował sobie administrację, co ten zachodni podział całkowicie zatarło.

Nie udało się przekonać posłów do przydatności Krajowego Związku Gmin, który miał z mocy prawa zrzeszać wszystkie gminy i miasta. Jako organizacja powszechna mógłby przejać w przyszłości wiele zadań regulacyjnych, edukacyjnych lub lobbystycznych. Cały rozdział traktujący w projekcie senackim o tym związku został usunięty. Spowodowało to w nieodległej przyszłości kłopoty z należytym wmontowaniem w system organów państwa regionalnych izb obrachunkowych, które miały być w założeniu instytucjami tworzonymi pospołu przez Krajowy Związek Gmin i rząd. Dyskusje nad nowym ich ustrojowym usytuowaniem przeciagały się w konsekwencji aż do jesieni 1992 r., tj. do uchwalenia ustawy o regionalnych izbach obrachunkowych ${ }^{12}$, gdy tymczasem nie było instytucji wyspecjalizowanej w nadzorze nad finansami gminnymi, a ogólny nadzór wojewody z natury rzeczy nie mógł być efektywny.

Pustkę organizacyjną po Krajowym Związku Gmin starały się dość szybko wypełnić tworzone spontanicznie przez gminy różnego rodzaju ich związki, jak Związek Miast Polskich, nawiązujaccy do podobnej organizacji o tej samej nazwie działającej w międzywojniu, czy Związek Gmin Wiejskich, Unia Metropolii Polskich oraz Unia Małych Miasteczek. Nie udało im się jednak zrzeszyć większości gmin, przez co siła ich realnego oddziaływania nigdy nie stała się wystarczająco duża.

Kolejnym punktem koncepcyjnego zderzenia się projektu senackiego z poselską wizją ustrojowa była bardzo istotna kwestia trybu odwoławczego w indywidualnych sprawach administracyjnych. Projekt senacki zakładał utworzenie kolegiów odwoławczych przy radach gmin. Miały one być powoływane przez radnych z grona specjalistów. Ta formuła została frontalnie zakwestionowana pod zarzutem braku dewolutywności, stąd ustawa o samorządzie terytorialnym w pierwotnym kształcie sytuowała kolegia odwoławcze przy sejmikach wojewódzkich, będących w tamtych okresie wojewódzką reprezentacją gmin. Z czasem samorządowe kolegia odwoławcze stały się organami państwa $^{13}$ i nie zmieniły swojego charakteru nawet po powołaniu wojewódzkich sądów administracyjnych jako sądów I instancji. Nadal działają na siatce 49 dawnych województw, tworząc niczym nieuzasadniony trójinstancyjny system odwoławczy w postępowaniu administracyjnym - system, w którym dominuje kasacyjny charakter rozstrzygania, bez możliwości na dobra sprawę sprawdzenia, czy decyzja I instancji jest merytorycznie trafna. Stawia to pytanie o konstytucyjność takiego trybu, w którym grona prawnicze badaja

${ }^{12}$ Ustawa z 7 października 1992 r. o regionalnych izbach obrachunkowych, Dz. U. 1992, Nr 85, poz. $428 \mathrm{ze} \mathrm{zm}$.

${ }^{13}$ Ustawa z 12 października 1994 r. o samorządowych kolegiach odwoławczych, Dz. U. Nr 122, poz. 593. 
niemal wyłącznie podstawę prawną decyzji i jej zgodność z prawem, podczas gdy interesariusz chce sprawdzić przede wszystkim jej merytoryczną trafność.

Ustawa w wersji sejmowej zwiększała zdecydowanie liczbę radnych, liczba ta $\mathrm{z}$ latami będzie sukcesywnie zmniejszana, ale proces sprowadzenia liczby radnych do rozsądnych granic trwał będzie kilkanaście lat. Niepotrzebnie też ustawa z 8 marca 1990 r. dawała sejmikom wojewódzkim kompetencję opiniowania kandydatów na wojewodów, co było kolejnym dowodem na swoista legislacyjną tęsknotą za systemem jednolitych organów państwa, bo tak przecież było w epoce rad narodowych.

Ponadto uchwalona przez Sejm ordynacja wyborcza do rad gmin wprowadzała wybory proporcjonalne we wszystkich gminach powyżej 40 tys. mieszkańców, co niewątpliwie przyspieszyło proces upolitycznienia (upartyjnienia) samorządu miejskiego.

W obliczu tak istotnego odejścia od treści ustawy sejmowej z 8 marca $1990 \mathrm{r}$. senacka Komisja Samorządu Terytorialnego wskazała uchwałą z 15 marca tegoż roku osiem istotnych błędów, które winny być skorygowane w trakcie dalszych prac legislacyjnych. Tok prac ustawodawczych w tamtym okresie miał jednak swoje polityczne uwarunkowania. Większość senatorów nie podzieliła zdania komisji samorządu terytorialnego, przede wszystkim z obawy o dalszy los reformy samorządowej i w obliczu ustalonej już daty wyborów samorządowych (odbyły się one 27 maja 1990). Senat ostatecznie przyją ustawę z 8 marca 1990 r. bez poprawek. Praktyka życia publicznego pokazała jednak, że niektóre ze wskazanych w uchwale komisji błędów były z czasem korygowane. Dotyczy to w szczególności liczby radnych, opiniowania kandydatów na wojewodów, ograniczenia działalności gospodarczej, która wbrew pierwotnym założeniom projektu senackiego nie podlegała w wersji sejmowej początkowo żadnym ograniczeniom. Niektóre popełnione wówczas błędy były usuwane dopiero w ostatnim czasie - tak stało się w przypadku wprowadzenia jednomandatowych okręgów wyborczych przed wyborami 2014 r. w odniesieniu do gmin wiejskich i mniejszych miast niebędących powiatami grodzkimi. Niektóre zaś rozwiązania sprzeczne z duchem pierwotnego założenia tkwią w systemie do dziś. Dotyczy to w szczególności braku administracyjnego kierownika urzędu gminy, który powinien brać odpowiedzialność za indywidualne decyzje administracyjne. System odwoławczy w tych sprawach nie wykraczałby wówczas poza ustrojowe i organizacyjne granice gminy, zachowujac merytoryczną kontrolę decyzji I instancji w rękach organów samej gminy, co uchroniłoby konstytucyjną zasadę jej samodzielności.

Trzeba także odnotować, że pierwotny projekt komisji senackiej nie przewidywał dzielenia zadań na własne i zlecone. Podział ten sięgajacy korzeniami rozwiązań samorządu pruskiego z początków XIX w., czyli z czasów dominacji Napoleońskiej, wydawał nam się już anachroniczny. Byliśmy przekonani, że lepiej będzie oddawać istotę podziału zadań pomiędzy rząd i samorząd zasada pomocniczości (subsydiarności), znana już EKSL, a w naszym projekcie wyrażona zasadą domniemania kompetencji gminy we wszystkich sprawach publicznych niezastrzeżonych ustawami dla innych organów państwa. Ostatecznie jednak katalog przykładowych zadań własnych został wprowadzony do ustawy samorządowej z uzasadnieniem, że w ten oto sposób katalog spraw 
właściwych tylko dla gminy nie będzie doznawał ograniczeń. Praktyka pokazała jednak, że rząd nigdy zadań samorządowi nie odbierał, przeciwnie - raczej katalog ten powiększał i powiększa z podkreśleniem, że zadania własne samorządu powinny być realizowane $\mathrm{z}$ dochodów własnych. To co więc miało chronić interesy samorządu w relacjach z rządem centralnym, obróciło się z czasem przeciwko samodzielności gmin ${ }^{14}$.

Warto także przypomnieć, że projekt senacki nie przewidywał tworzenia specjalnego ustroju dla Warszawy. Jej specyfikę planowano regulować - identycznie tak jak w przypadku wszystkich miast powyżej 300 tys. mieszkańców w drodze statutów zatwierdzanych przez rząd. Odrębna ustawa o ustroju miasta stołecznego Warszawy pojawiła się w maju 1990 r., dzieląc niedorzecznie miasto na siedem odrębnych dzielnic i nadając im cechy odrębności ustrojowej gminy. Jeszcze przed końcem pierwszej kadencji rady Warszawy uchwalono drugą jej wersję, tym razem dzielącą Warszawę na 11 dzielnic o statusie gmin. Ta regulacja również nie zdała egzaminu - ostatecznie kolejną ustawa z 15 marca 2002 r. o ustroju miasta stołecznego Warszawy ${ }^{15}$ przekształcono stolicę w jeden organizm gminny, z podziałem na dzielnice w celu sprawniejszego zarządzania, co w istocie jest powrotem do pierwotnej koncepcji rozwiązania tej kwestii.

\section{PIERWSZE WYBORY SAMORZĄDOWE}

Pierwsze wybory do rad gmin odbyły się 27 maja 1990 r., a frekwencja w skali kraju nie przekroczyła 43\%. Musiało to rozczarowywać wszystkich entuzjastów lokalnej samorządności, ale trzeba też podkreślić, że stały się one istotną cezurą w rozwoju Polski lokalnej, która szybko zaczęła zmieniać swoje oblicze - przede wszystkim z uwagi na niespotykana dotychczas skalę inwestycji infrastrukturalnych. Efekty tej strony działalności polskiego samorządu sa dobrze opisane i powszechnie znane, tu podkreślmy tylko, że powierzenie zarządu mieniem komunalnym władzom publicznym, posiadającym od czasów przedwojennych w pełni praworządną legitymację, uruchomiło olbrzymie pokłady energii, która w zdecydowanej większość gmin została właściwie ukierunkowana. Porządkowanie, szczególnie w pierwszym okresie, tytułów własności nieruchomości miejskich, pozwoliło sprawnie zarządzać tymi składnikami mienia, a jednocześnie otworzyć Polskę lokalną na przypływ inwestycji zagranicznych - nie tylko w postaci środków finansowych, ale przede wszystkim nieznanej tu wcześniej technologii.

Niemal na drugi dzień po wyborach samorządowych i ukonstytuowaniu się zarządów można było zauważyć niezwykle ciekawe zjawisko o dalekosiężnych

${ }_{14}$ Więcej na ten temat: J. Stępień, Niestrzeżona granica. Kilka uwag o decentralizacji zadań publicznych, w: S. Fundowicz, F. Rymarz, A. Gomułowicz (red.), Prawość i godność. Księga pamiatkowa $w$ 70. rocznice urodzin Profesora Wojciecha Eaczkowskiego, Katolicki Uniwersytet Lubelski, Lublin 2003, s. 257-273.

15 Dz. U. 2002, Nr 41, poz 361. 
skutkach dla ostatecznego ukształtowania się ustroju terytorialnego w niedalekiej przyszłości. Mowa już była o ustawie o terenowych organach administracji ogólnej. Ośrodek rządowy skupiony wokół prof. Jerzego Kołodziejskiego planował początkowo utworzenie około 150 rejonów administracji ogólnej. Pierwsza wersja mapy rejonów, ogłoszona po wyborach samorządowych, wywołała nadspodziewaną reakcję nowo wybranych władz gminnych. Mapa tych ośrodków dalece odbiegała od mapy powiatów sprzed 1975 r., wiele dawnych powiatów nie odnalazło się na mapie rejonów, co uznano w tych miejscowościach za zapowiedź ich swoistej degradacji. Siła tej reakcji była tak wielka, a lobbing tak skuteczny, że ostateczna siatka rejonów, utworzona w sierpniu 1990 r., obejmowała 268 jednostek. Rejony administracji ogólnej, zarządzane jednoosobowo przez podległego hierarchii rządowej urzędnika, przejęły wiele istotnych zadań i kompetencji dawnej administracji szczebla wojewódzkiego, ale także i gminnego, co było powodem licznych tarć w ramach nowo utworzonej administracji w ogóle. Narastające napięcia wymagały w przyszłości ustrojowej reakcji, mogła ona przebiegać tylko w dwóch kierunkach: albo z założeniem ostatecznej likwidacji rejonów, albo przez ich usamorządowienie. Rozwój sytuacji w najbliższych latach, szczególnie nacisk lokalnych elit, a także skutki pilotażu, polegającego na przejęciu przez niektóre większe ośrodki miejskie zadań administracji rządowej (szczególnie w zakresie oświaty i pomocy społecznej), dyktował ten drugi kierunek, co ostatecznie stało się w 1998 r. w wyniku II etapu reformy samorządowej. Wprowadziła ona ostatecznie 16 województw rządowo-samorządowych oraz 314 powiatów ziemskich i 65 grodzkich, przy wyraźnym sprzeciwie rządu wobec mnożenia bytów - zarówno wojewódzkich, jak i powiatowych.

\section{W POSZUKIWANIU PARADYGMATU POLSKIEJ SAMORZĄDNOŚCI}

Jeśli zachodni paradygmat samorządności terytorialnej kładzie nacisk w myśl Europejskiej karty samorządu terytorialnego - na wspólnotowość, partycypacyjność obywatelską i kolegialność decyzji o charakterze politycznym i strategicznym, z wyraźnym odróżnieniem poziomu politycznego (wybór) od administracyjnego (urzędniczego), a wschodni model władzy publicznej preferuje przede wszystkim jednoosobowe organy decyzyjne, przy zatarciu granicy pomiędzy sferą polityczną i administracja, to da się w ciagu minionego dwudziestopięciolecia samorządu zaobserwować wyraźne przesunięcie akcentów na ten drugi model. Przejawia się to najwyraźniej w tych zmianach kształtu władzy lokalnej, które prowadziły do sukcesywnego osłabiania pozycji rady i tym samym marginalizowania jej roli, przy równoczesnym wzmacnianiu pozycji organu wykonawczego. Już w 1994 r. pojawiła się pierwsza próba wprowadzenia wyborów bezpośrednich wójta, początkowo jako nadal przewodniczącego wieloosobowego zarządu gminy, szczęśliwie wówczas zawetowana przez prezydenta. Starania te ponowiono, tym razem skutecznie, w 2002 r., tworząc dodatkowo w miejsce dotychczasowego wieloosobowego zarządu jednoosobowy 
organ wykonawczy. Warto może odnotować w tym miejscu, że zarówno Jerzy Regulski, jak i Michał Kulesza, a także niżej podpisany, starali się przekonać komisję sejmową przed podjęciem w tej sprawie tak istotnej decyzji, że jednoosobowy model organu wykonawczego będzie prowadził do zjawisk nepotyzmu i ograniczenia w istotny sposób kontrolnej funkcji rady. Argumenty te nie trafiły posłom do przekonania. Jednoosobowy organ wykonawczy, charakterystyczny dla stricte administracyjnej pozycji urzędu w krajach o utrwalonych tradycjach demokratycznych, zają w naszych warunkach pozycję polityczna o bardzo silnej legitymacji, związanej z bezpośrednim wyborem. Wprowadzano go z uzasadnieniem potrzeby odpolitycznienia samorządu i w pierwszej kadencji po wprowadzeniu tego modelu wyboru mogło się wydawać, że temu celowi sprzyja. Praktyka ostatnich lat dowodzi jednak, że partie polityczne nie tylko odzyskały dawny wpływ na kształt osobowy samorządu, szczególnie w dużych miastach, lecz że ten wpływ wzmocniły. Ostatnio często powraca w dyspucie publicznej postulat ograniczenia kadencyjności wójtów, burmistrzów i prezydentów do dwóch kadencji jako remedium na system wzajemnych powiąań utrwalających zjawiska patologiczne. Trzeba jednak z góry przestrzec, że tego rodzaju ograniczenie nie tylko nie rozwiązuje potrzeb bieżącej praktyki (takie ograniczenie może działać tylko pro futuro), ale odsuwa na bok usunięcie zasadniczego powodu patologii organizacyjnej i zarządczej, jaką jest łączenie w jednym ręku funkcji politycznej i administracyjnej.

Bezpośredni wybór wójta doprowadził także do całkowitego wynaturzenia instytucji absolutorium z wykonania budżetu, skoro w tej chwili nieudzielenie absolutorium może być jedynie podstawą wszczęcia procedury referendalnej zmierzającej do odwołania wójta. Wprowadzenie bezpośredniego wyboru wójta nastapiło w wyniku zmiany trybu przewidzianego w ordynacji wyborczej, tak jakby kwestia modelu wyboru była jedynie problemem wyborczym, a nie kwestią ustrojowa. Dowodzi to swoistej nonszalancji ustawodawcy, dla którego kwestie związane z trybem kreowania władzy publicznej poprzez wybory okazały się ważniejsze od prawidłowego rozwiązania relacji pomiędzy organami gminy z punktu widzenia ich zasadniczych funkcji.

Całkowitym odejściem od pierwotnej idei wspólnotowości gminy okazała się wprowadzona Kodeksem wyborczym z 2011 r. możliwość kandydowania na stanowisko wójta (burmistrza, prezydenta) osoby niebędącej stałym mieszkańcem danej gminy ${ }^{16}$. Tego rodzaju rozwiązanie może odnosić się wyłącznie do osób zajmujaccych stanowiska administracyjne, ale nie w odniesieniu do politycznego stanowiska pochodzącego w wyboru. W aktualnej konstrukcji prawnoustrojowej „pierwszym obywatelem” gminy może stać się osoba, która nigdy wcześniej w danej miejscowości nie mieszkała. Niewątpliwie ten mechanizm sprzyja kierowaniu przez partie swoich funkcjonariuszy na najważniejsze stanowiska, podobnie jak było to zasadą w okresie przed 1990 r., ale mało to ma wspólnego z zachodnią zasadą reprezentacji.

Zachodnioeuropejski paradygmat władzy publicznej według Samuela Huntingtona $^{17}$ to także, poza przywołaną już zasadą reprezentacji, prymat pra-

${ }_{16}$ Art. 11 ust. 6 ustawy z 5 stycznia 2011 r. - Kodeks wyborczy, Dz. U. Nr 21, poz. 112.

17 S. P. Huntington, op. cit., s. 103. 
wa oraz wyraźny podział na sferę publiczną i prywatną. Warto z punktu widzenia zasady prymatu prawa prześledzić losy planowania przestrzennego po 1990 r. Była już mowa o tym, że zarówno prof. Jerzy Regulski, jak i prof. Michał Kulesza zbliżyli się do samorządu od strony problematyki zagospodarowania przestrzennego. Stała się ona nawet punktem nr $1 \mathrm{w}$ katalogu zadań własnych, jeśli już ten katalog musiał powstać. Mowa w nim o ładzie przestrzennym i gospodarce terenami ${ }^{18}$.

Plan szczegółowy zagospodarowania przestrzennego jest aktem prawa miejscowego, czyli aktem normatywnym wymienionym w katalogu źródeł prawa (art. 87 ust. 2 Konstytucji z 2 kwietnia 1997 r.).

Cokolwiek dałoby się powiedzieć o planach przestrzennych sprzed 1990 r., to jedno jest niewątpliwe: w wielu miastach i gminach takie plany w 1990 r. istniały. Wydawać by się mogło, że praktyka w nowych warunkach ustrojowych powinna sprzyjać chronieniu tychże planów i ich doskonaleniu. Rzeczywistość potoczyła się w zgoła innym kierunku. W 1994 r. zdecydowano o utracie mocy wiążącej planów zagospodarowania przestrzennego po upływie 5 lat od daty wejścia w życie nowej ustawy i jednocześnie nałożono na gminy obowiązek uchwalenia studium uwarunkowań i kierunków zagospodarowania przestrzennego $^{19}$. Z góry można było przewidzieć, że wykonanie tego obowiąz$\mathrm{ku}$ jest nierealne, a to $\mathrm{z}$ uwagi na olbrzymie koszty z tym związane. Tak się też stało. Aktualnie decyzje lokalizacyjne w miejscowościach, gdzie planów nie ma, wydawane sa po uprzednim uzyskaniu tzw. wuzetki, czyli decyzji o warunkach zabudowy. Tam gdzie nie ma aktualnego planu zagospodarowania przestrzennego, pozwolenie na budowę wydawane jest z uwzględnieniem mitycznego prawa sassiedztwa, które nie jest określone normatywnie. W konsekwencji cały budowlany proces inwestycyjny odbywa się wyłącznie w drodze uzyskiwania decyzji administracyjnych. Powoduje to olbrzymi chaos urbanizacyjny i jest źródłem wielu kolejnych patologii. Z punktu widzenia interesujacych nas w tym szkicu rozważań widać natomiast wyraźnie, że zasada prymatu prawa (plan miejscowy, jako akt normatywny) ustapiła w tym przypadku sile woluntarystycznej decyzji organu jednoosobowego (wójta).

$$
* * *
$$

W świetle przytoczonych faktów można postawić tezę, że z punktu widzenia pierwotnych założeń procesu przywracania samorządu terytorialnego cały proces przebudowy systemu władzy lokalnej można przedstawić jako serię kolejnych odstępstw od początkowej wizji, i co więcej - jako ciag porażek sprowadzajacych ambitne senackie „wychylenie się na Zachód” na naszą dobrze uklepaną ziemię, leżącą od wieków pomiędzy Wschodem i Zachodem. Obie te wizje maja, co zrozumiałe, swoich zwolenników. Nasz samorząd stanął w wyniku tej konfrontacji niejako na granicy podziału cywilizacyjnego wyrażonego z jednej strony paradygmatem rządów ojców miasta, a z drugiej - wizją jednoosobowych rządów gospodarza.

18 Art. 7 ust 1 pkt 1 ustawy o samorządzie terytorialnym z 8 marca $1990 \mathrm{r}$.

19 Art. 67 ustawy z 7 lipca 1994 r. o zagospodarowaniu przestrzennym, Dz. U. 1994, Nr 89, poz. 415 . 
Po stronie zachodniej trzyma nas jeszcze instytucja osobowości prawnej wspólnoty (nieco już jednak nadwyrężona koncepcją „gospodarza” gminy spoza jej wspólnoty) oraz kategoria mienia komunalnego, odrębnego od mienia ogólnopaństwowego. Dodać do tego trzeba instytucję odrębnych od budżetu państwa budżetów lokalnych oraz zasadę nadzoru legalnego, choć już pojawiają się głosy, że władza centralna powinna czasami chronić samorząd przed merytorycznie nietrafnymi decyzjami.

Przyszłość pokaże, dokąd nam bliżej. Chodzi oczywiście nie o deklarowana wolę przynależności, ale o treść, określająca rzeczywisty kierunek rozwoju. W warstwie deklaracyjnej wszyscy chcielibyśmy zachodniej wizji dalszego rozwoju i takich jak tam osiagnięć w postaci wspaniałych miast, uniwersytetów, infrastruktury, poziomu technicznego itd. Często jednak chcielibyśmy te cele osiagać metodami charakterystycznymi dla wschodniego modelu sprawowania władzy. Trzeba jednak stale pamiętać, że termin „cywilizacja”, pochodzi od łac. civis (obywatel). Decydująca jest zatem nie techniczna i infrastrukturalna, niejako zewnętrzna postać organizacji życia publicznego, lecz rzeczywista pozycja obywatela zarówno w układzie horyzontalnym wobec innych obywateli, jak i przede wszystkim w relacjach obywatela z władza. Zachodnich efektów cywilizacyjnych nie da się bowiem osiagnać wschodnimi metodami. Zachodnia pozycja obywatela to realny jego wpływ na władzę centralna, lokalną i regionalna. Wschodni model zawsze mniej interesował się mechanizmami tworzenia centralnego ośrodka władzy, ale zawsze z pokora przyjmował, że dół zależy od góry.

prof. Jerzy Stepień

Uczelnia Eazarskiego w Warszawie,

b. Prezes Trybunatu Konstytucyjnego,

Przewodniczacy Senackiej Komisji Samorzqdu Terytorialnego w latach 1989-1993

\title{
IN SEARCH OF THE CONTEMPORARY SHAPE OF SELF-GOVERNMENT
}

\author{
Sum mary
}

The twenty-fifth anniversary of self-government in Poland is a good occasion to reflect on the road we have travelled so far. While we still remember well the intentions of the creators of the system (members of the First Senate) we can now compare them with the current state of affairs and the status quo of government in Poland today. Two concepts have always been there since the beginning. Whereas the original solutions were to be inscribed in the tradition of Polish self-government, everything was done from the very start to draw as much as possible from the achievements of legal political thinking, later manifested in the provisions of the European Charter on Local Self-Government - a document which is the quintessence of the Western model of a local authority. Self-government is an institution characteristic of Western civilisation, practically unknown elsewhere, and it extends the principles of representation onto the local space inhabited by its citizens. Examples offered in the article illustrate how the initially planned model of government in Poland, rooted in the city fathers model has, in the course of subsequent reforms, been losing its original Western clarity in favour of the previous host model of local authority that characterised the past system. 
